\title{
Two new species of the family Rhynchitidae (Coleoptera: Curculionoidea) from Eocene Baltic amber, with key to species and assumed trophic relationships
}

\author{
Andris Bukejs ${ }^{1}$ and Andrei A. Legalov ${ }^{2,3,4}$ \\ ${ }^{1}$ Institute of Life Sciences and Technologies, Daugavpils University, Vienības 13, Daugavpils, 5401, Latvia \\ ${ }^{2}$ Institute of Systematics and Ecology of Animals, Siberian Branch, Russian Academy of Sciences, Frunze Street 11, \\ Novosibirsk 630091, Russia \\ ${ }^{3}$ Department of Ecology, Biochemistry and Biotechnology, Altai State University, Lenina 61, Barnaul 656049, Russia \\ ${ }^{4}$ Department of Forestry and Landscape Construction, Tomsk State University, Lenin Ave, 36, Tomsk 634050, Russia
}

Correspondence: Andrei A. Legalov (fossilweevils@gmail.com)

Received: 28 January 2021 - Revised: 29 March 2021 - Accepted: 30 March 2021 - Published: 4 May 2021

\begin{abstract}
Two new fossil species of Baltocar Kuschel, 1992 and Pseudomesauletes Legalov, 2001 (Curculionoidea: Rhynchitidae) are described from Eocene Baltic amber. Baltocar sontagae sp. nov. is similar to B. groehni Riedel, 2012 but differs in the shorter rostrum, tarsomere 1 shorter than tarsomere 5 and $1.4 \times$ as long as tarsomere 2, longer elytra, and shorter body. Pseudomesauletes lobanovi sp. nov. is similar to P. culex (Scudder, 1893) and P. ibis (Wickham, 1912): the new species differs from $P$. culex in the larger eyes, longer pronotum, being $0.44 \times$ shorter than elytra, and slightly smaller body size; from $P$. ibis it differs in the smaller body size, rostrum shorter than elytra, and weakly convex pronotum. This is the first record of Pseudomesauletes from Baltic amber and the sixth species of Baltocar. Keys to species of the genus Baltocar and to the Eocene species of the genus Pseudomesauletes are given. Assumed trophic relationships of these fossil taxa are discussed (urn:Isid:zoobank.org:pub:260EBE6E-DA6C-4D6DA1D2-2C258224622F).
\end{abstract}

\section{Introduction}

Beetles of the family Rhynchitidae have more than 2000 described species in the Holocene fauna (Legalov, 2015a). Representatives of this family are distributed almost everywhere, with the centre of diversity in the tropics and subtropics (Legalov, 2007). The rhynchitid larvae develop in the dead parts of the plant, usually gnawed by the female (Legalov, 2004). Thirty-five species were found in the fossil record (Legalov, 2015b; Bukejs and Legalov, 2019; Kania and Legalov, 2019). The earliest Rhynchitidae are known from the Cenomanian of Botswana and the Turonian New Jersey amber (Gratshev and Zherikhin, 2000; Legalov, 2015b). They are found in the Paleocene of France (Legalov, 2020b), the Eocene of the USA and Europe (Legalov, 2015b, 2020b), the Oligocene of Europe (Legalov, 2020b), the Miocene of Germany (Heer, 1847), and also Dominican and Mexican amber (Poinar and Brown, 2007; Poinar and Legalov, 2015). Nine rhynchitid species are described from Eocene Baltic amber (Voss, 1953; Legalov, 2012, 2013, 2015b, 2020a, b; Riedel et al., 2012; Kania and Legalov, 2019). The extinct genus Baltocar Kuschel, 1992 includes five species (Riedel et al., 2012; Legalov, 2015b, 2020a). A new species of this genus is discovered in examined Baltic amber material. The fossil species of the genus Pseudomesauletes Legalov, 2001 were known from Rovno amber (Bukejs and Legalov, 2019) and Florissant (Legalov, 2015b). A newly described species is the first record of this genus from the Baltic amber.

\section{Material and methods}

The material examined is deposited in the collection of the Museum of Amber Inclusions, University of Gdańsk (Poland) (MAIG). The amber pieces were polished by hand, 
allowing improved views of the included specimens and were not subjected to any supplementary fixation.

The photographs of specimens were taken using a Canon $70 \mathrm{D}$ camera with a macro lens (Canon MP-E $65 \mathrm{~mm}$ ). Extended depth of field at high magnifications was achieved by combining multiple images from a range of focal planes using Helicon Focus v. 6.0.18 software, and the resulting images were edited to create figures using Adobe Photoshop CS5.

The X-ray micro-CT observations of specimen 6703 (MAIG) were conducted at Daugavpils University, Daugavpils, Latvia (DU), using a Zeiss Xradia 510 Versa system. Scans were performed with a polychromatic X-ray beam at an energy of $40 \mathrm{kV}$ and power of $3 \mathrm{~W}$. Sample-to-detector distance was set to $17.5 \mathrm{~mm}$, and source-to-sample distance was $47.7 \mathrm{~mm}$. Tomographic slices were generated from 3001 rotational steps through a $360^{\circ}$ rotation, using a $4 \times$ objective. The exposure time during each projection was set to $5 \mathrm{~s}$. Acquired images were binned $(2 \times 2 \times 2)$, giving a voxel size of $4.87 \mu \mathrm{m}$. Images were imported into the Dragonfly PRO (ver. 4.1) software platform for interactive segmentation and $3 \mathrm{D}$ visualization.

Morphological terminology follows Legalov (2007) and Lawrence et al. (2010).

\section{Systematic paleontology}

Order Coleoptera Linnaeus, 1758

Suborder Polyphaga Emery, 1886

Superfamily Curculionoidea Latreille, 1802

Family Rhynchitidae Gistel, 1848

Subfamily Sayrevilleinae Legalov, 2003

Tribe Sayrevilleini Legalov, 2003

Genus Baltocar Kuschel, 1992

Baltocar sontagae sp. nov. urn:lsid:zoobank.org:act:1B0A90AB-068E-4D98976E-291FC55B410A

Figs. 1-2.

\section{Etymology}

Patronymic. This new species is named in honour of our colleague Elżbieta Sontag (Gdańsk, Poland), who provided us the opportunity to study this interesting fossil specimen.

\section{Type material}

Holotype. Collection number "6703" (MAIG) (ex. coll. Jonas Damzen JDC 9012), "Holotype/Baltocar/sontagae sp. nov./Bukejs et Legalov des. 2021" (red printed label); adult, sex apparently female. A complete beetle included in a transparent, yellow amber piece with approximate dimensions of $24 \mathrm{~mm} \times 5 \mathrm{~mm}$ and a maximum thickness of $4 \mathrm{~mm}$, preserved without supplementary fixation. The right part of the specimen is partially obscured by milky amber. Syninclusions: one Brachycera (Diptera) specimen.

\section{Type stratum}

A predominantly Bartonian age (41.3-37.9 Ma) is interpreted for the extinct central European resin-producing forests, which produced the amber that has eroded out of Eocene Blue Earth layers (Bukejs et al., 2019). However, the vast majority of Baltic amber derives from the geological amber-bearing strata of the certainly Priabonian age (37.8 33.9 Ma) (Sadowski et al., 2017, 2020).

\section{Type locality}

Baltic Sea coast, Yantarny settlement (formerly Palmnicken), Sambia (Samland) Peninsula, Kaliningrad Region, Russia.

\section{Description}

Measurements. Body length (without rostrum) about $2.4 \mathrm{~mm}$, body maximum width $1.1 \mathrm{~mm}$; rostrum length $0.82 \mathrm{~mm}$, rostrum width basally $0.16 \mathrm{~mm}$, medially $0.12 \mathrm{~mm}$, apically $0.20 \mathrm{~mm}$; pronotum length $0.7 \mathrm{~mm}$, pronotum maximum width $0.6 \mathrm{~mm}$; elytra length $1.7 \mathrm{~mm}$, elytra maximum combined width $1.1 \mathrm{~mm}$.

Body. Unicolourous black (as preserved). Pubescence: pronotum with sparse, short, semierect thin setae; elytra with sparse, short, recumbent to slightly semierect setae; and ventral side of body with sparse, fine, recumbent setae.

Head. Forehead flat, with middle furrow; vertex convex, covered with sparse and fine punctation; temples $0.6 \times$ as long as horizontal diameter of one eye, with sparse and fine punctation. Rostrum rather long, 1.1 times as long as pronotum, slightly curved (in lateral view), widened apically (in dorsal view), about $5.1 \times$ as long as wide basally, $6.8 \times$ as long as wide medially, and $4.1 \times$ as long as wide apically; covered with very fine and sparse punctures. Compound eyes large, oval, strongly convex, vertical diameter about $0.7 \times$ as horizontal diameter. Maxillary palpi with four palpomeres.

Antennae. With 11 antennomeres, not geniculate, with distinct three-antennomered club; moderately long, about $1.2 \times$ as long as rostrum, reaching elytral posterior margin, inserted at base of rostrum; scape cylindrical, $2.4 \times$ as long as wide, and almost as long as antennomere 2; antennomere 2 subcylindrical, about $2.2 \times$ as long as wide, as wide as scape and $1.7 \times$ as wide as antennomere 3 ; antennomeres $3-6$ subconi- 


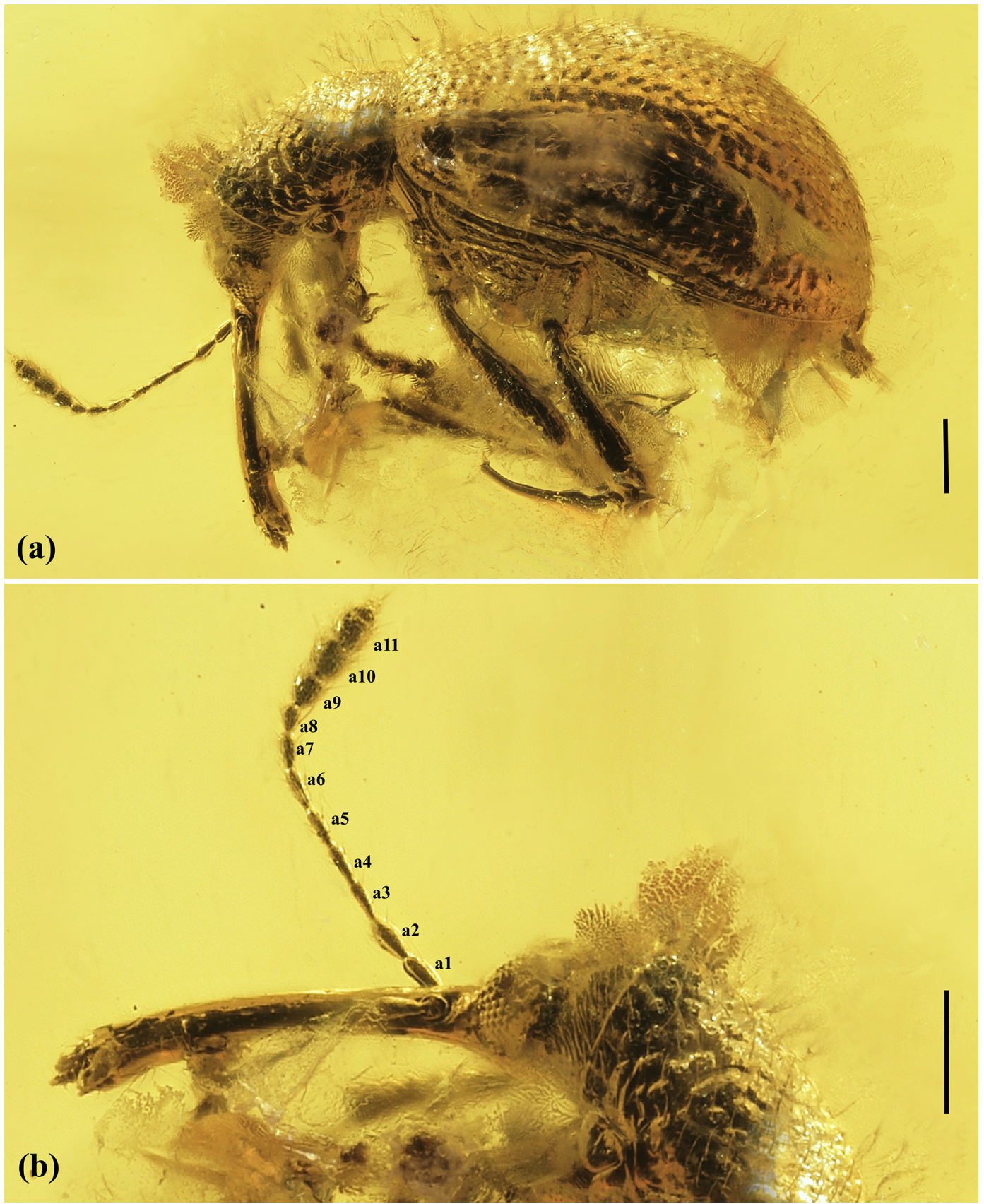

Figure 1. Photomicrographs of Baltocar sontagae sp. nov., holotype, 6703 (MAIG): (a) habitus, left lateral view; (b) details of forebody, lateral view. Scale bars $=0.25 \mathrm{~mm}$. Abbreviations: a1-a11 denote antennomeres 1-11.

cal, elongate, $3.3 \times$ as long as wide, equal in size and shape; antennomere 7 conical, about $2.7 \times$ as long as wide, slightly shorter than antennomere 6; antennomere 8 shortest, $2 \times$ as long as wide; antennal club (antennomeres $9-11$ ) about $0.5 \times$ as long as flagellum (antennomeres 2-8); antennomere 9 about $1.1 \times$ as long as wide, dilated apically, about $2.2 \times$ as wide as antennomere 8 ; antennomere 10 about $1.1 \times$ as long as wide, slightly wider than antennomere 9 , slightly dilated apically; antennomere 11 spindle-shaped with pointed apex,
$1.6 \times$ as long as wide; relative length ratios of antennomeres $1-11$ equal to $12: 11: 10: 10: 10: 10: 8: 6: 8: 9: 13$.

Pronotum. Bell-shaped, elongate, $1.6 \times$ as long as wide at apex, $1.4 \times$ as long as wide in middle and at base, widest in posterior one-fifth, gradually narrowed anteriad; moderately densely covered with small punctuation; irregularly rugose; disc flat; lateral margins straight, posterior margin distinctly convex, anterior margin convex in dorsal view. 


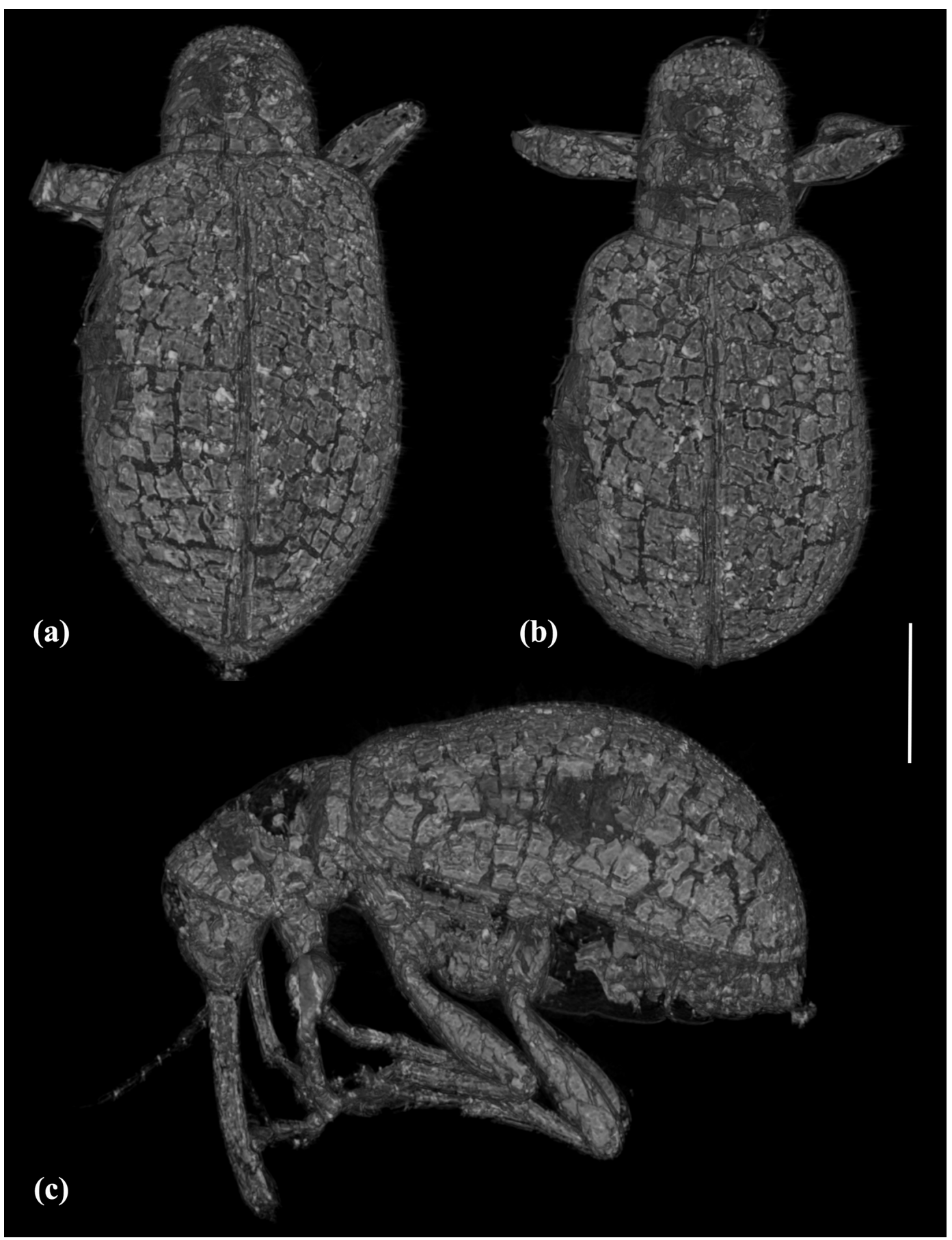

Figure 2. X-ray micro-CT renderings of Baltocar sontagae sp. nov., holotype, 6703 (MAIG), habitus: (a) dorsal view; (b) dorso-frontal view; (c) left lateral view. Scale bar $=0.5 \mathrm{~mm}$.

Scutellum. Minute, subtriangular, poorly visible in studied specimen.

Elytra. Widely oval, elongate, convex, $2.3 \times$ as long as wide combined at anterior margin, $1.5 \times$ as long as wide combined medially, $2.0 \times$ as long as wide combined in posterior one-quarter, widest behind middle, $2.4 \times$ as long as pronotum; elytral base concave, distinctly wider than poste- rior pronotal margin; humeral callus weak; elytral punctation small and rather dense (punctures at lateral sides distinctly sparser), forming regular rows, distance between punctures in rows equal to $0.7-2.0 \times$ diameter of puncture, intervals slightly convex, distance between rows about $2.0-3.5 \times$ diameter of puncture. 
Thorax. Prohypomera with fine and rather sparse punctation. Pre- and postcoxal parts of prosternum short, subequal in length. Epipleuron narrow, with fine punctures. Metaventrite with small punctation at lateral sides; disc convex. Metepisternum narrow, about $6.3 \times$ as long as wide medially; with fine punctation.

Legs. Rather long, slender. Procoxae conical, located in middle of prosternum; mesocoxae round; metacoxae oval, transverse, slightly shorter than abdominal ventrite 1 . Femora clavate, slightly swollen in apical portion, covered with fine, sparse punctation; profemora about $3.7 \times$ as long as wide medially, metafemora about $3.9 \times$ as long as wide medially. Tibiae cylindrical, almost straight (protibiae slightly curved), with sparse and fine punctures, with fringe of dark spinulae apically, and apparently with two small apical spurs (distinctly visible on protibiae); protibial about $9 \times$ as long as wide medially, metatibia about $6 \times$ as long as wide medially. Tarsi long, slightly shorter than tibiae, metatarsus about $0.8 \times$ as long as metatibia; tarsomere 1 elongate, slightly dilated apically, tarsomere 2 subconical, elongate, tarsomere 3 bilobed, nearly as long as wide, apical tarsomere subcylindrical, elongate, slightly curved; metatarsomere 1 about $2.9 \times$ as long as maximum wide, shorter than tarsomere 5 and 1.4 times as long as tarsomere $2,0.4 \times$ as long as tarsomeres $2-$ 5 combined, metatarsomere 2 about $2.1 \times$ as long as maximum wide, metatarsomere 3 about $1.1 \times$ as long as maximum wide, apical metatarsomere about $5.5 \times$ as long as maximum wide; relative length ratios of metatarsomeres $1-3,4$ subequal to $4: 3: 2: 4$. Tarsal claws strongly divergent, free, simple.

Abdomen. Convex, covered with small and sparse punctation; all sutures distinct, complete and straight; ventrites 1 and 2 equal in length, ventrite 3 about $0.7 \times$ as long as ventrite 2 , ventrite 4 about $0.8 \times$ as long as ventrite 3 , ventrite 5 smallest, about $0.7 \times$ as long as ventrite 4 , with widely rounded apical margin; relative length ratios of ventrites $1-5$ equal to $6: 6: 4: 3: 2$ (medially).

\section{Note}

Sex of examined specimen determined based on micro-CT results. There is no sclerotized structure resembling aedeagus inside the abdominal cavity; therefore, the specimen appears to be female.

\section{Comparison}

Baltocar sontagae sp. nov. is similar to B. groehni Riedel, 2012 but differs in the shorter rostrum; tarsomere 1 shorter than tarsomere 5 and 1.4 times as long as tarsomere 2; longer elytra and shorter body.

\section{Key to the species of the genus Baltocar}

(according to Riedel et al. (2012) and Legalov (2020a) with modifications)
1. Elytral punctation irregular. Rostrum shorter or subequal to pronotum (p. 2).

- Elytral punctation forming regular rows. Rostrum longer or subequal to pronotum (p. 3).

2. Body covered with dense setae. Rostrum slightly curved, subequal to pronotum (convexus Legalov, 2015b).

- Body without distinct pubescence. Rostrum distinctly curved, shorter than pronotum (subnudus Riedel, 2012)

3. Pronotal disc coarsely punctate. Setae widened (succinicus (Voss, 1953)).

- Pronotal disc transversely irregularly rugose. Setae narrow (p. 4).

4. Pronotum with slightly rounded lateral sides, about $1.1 \times$ as long as wide. Tarsomere 1 about $0.6 \times$ as long as tarsomeres 2-5 combined (hoffeinsorum Riedel, 2012).

- Pronotum with subparallel lateral sides (Fig. 2c), $1.4 \times$ as long as wide. Tarsomere 1 about $0.4 \times$ as long as tarsomeres $2-5$ combined (p. 5).

5. Rostrum long, $18.0 \times$ as long as wide medially. Tarsomere 1 slightly longer than tarsomere 5 and $1.2 \times$ as long as tarsomere 2. Elytra $1.2 \times$ times as long as maximum combined width. Body longer, $2.9 \mathrm{~mm}$ (groehni Riedel, 2012).

- Rostrum shorter, $6.8 \times$ as long as wide medially. Tarsomere 1 shorter than tarsomere 5 and $1.4 \times$ as long as tarsomere 2. Elytra $1.5 \times$ as long as maximum combined width. Body shorter, $2.4 \mathrm{~mm}$ (sontagae sp. nov.).

\section{Remarks}

The studied amber specimen possesses the combination of characters corresponding to the family Rhynchitidae: antennae not geniculate, quite long ventrites 3 and 4, narrow epipleuron, tarsal claws free at base, not extended tarsomere 1. Strongly divergent tarsal claws suggest placement in the subfamily Sayrevilleinae and tarsal claws lacking teeth assignments of the specimen to the tribe Sayrevilleini. The new species belongs to the genus Baltocar based on the short precoxal portion of the prosternum and forehead with middle furrow.

Subfamily Rhynchitinae Gistel, 1848

Tribe Auletini Desbrochers des Loges, 1908

Subtribe Pseudomesauletina Legalov, 2003 
Genus Pseudomesauletes Legalov, 2001

Subgenus Pseudomesauletes Legalov, 2001

Pseudomesauletes (Pseudomesauletes)

lobanovi sp. nov.

urn:Isid:zoobank.org:act:98039B3C-9475-479D-AF444F3A7B1AB824

Fig. 3.

\section{Etymology}

Patronymic. The name of this new species is dedicated to the memory of the late Andrey L'vovich Lobanov, known specialist in Cerambycidae and founder of coleopteran website "Beetles and Coleopterists" (http://www.zin.ru/animalia/ coleoptera/eng, last access: 30 April 2021).

\section{Type material}

Holotype: collection number "6701" (MAIG) (ex. coll. Jonas Damzen JDC 9318), "Holotype/Pseudomesauletes/lobanovi sp. nov./Bukejs et Legalov des. 2021" (red printed label); adult, female. A complete beetle included in a transparent, yellow amber piece with approximate dimensions of $33 \mathrm{~mm} \times 11 \mathrm{~mm}$ and a maximum thickness of $7 \mathrm{~mm}$; preserved without supplementary fixation. Syninclusions: one Diptera specimen, body parts (legs and wing) of cf. Diptera, few stellate trichomes, and some small gas vesicles.

\section{Type stratum}

A predominantly Bartonian age $(41.3-37.9 \mathrm{Ma})$ is interpreted for the extinct central European resin-producing forests, which produced the amber that has eroded out of Eocene Blue Earth layers (Bukejs et al., 2019). However, the vast majority of Baltic amber derives from the geological amber-bearing strata of the certainly Priabonian age (37.833.9 Ma) (Sadowski et al., 2017, 2020).

\section{Type locality}

Baltic Sea coast, Yantarny settlement (formerly Palmnicken), Sambia (Samland) Peninsula, the Kaliningrad Region, Russia.

\section{Description}

Measurements. Body length (without rostrum) about $3.3 \mathrm{~mm}$, body maximum width $1.4 \mathrm{~mm}$; rostrum length $1.9 \mathrm{~mm}$, rostrum width basally $0.3 \mathrm{~mm}$, medially $0.2 \mathrm{~mm}$, apically $0.3 \mathrm{~mm}$; pronotum length $1.0 \mathrm{~mm}$, pronotum maximum width $0.9 \mathrm{~mm}$; elytra length $2.2 \mathrm{~mm}$, elytra maximum width $1.4 \mathrm{~mm}$.

Body. Brown (as preserved), head and rostrum dark brown. Pubescence: rather dense, short and recumbent.
Head. Dorsally covered with small, sparse punctation, distance between punctures about $0.5-1.5 \times$ diameter of one puncture, ventrally with sharp transverse wrinkles and very sparse punctation; forehead wide, convex; vertex slightly impressed. Rostrum very long, about $1.9 \times$ as long as pronotal length, almost straight (in lateral view), widened to apex (in dorsal view), about $6 \times$ as long as wide basally, $9.5 \times$ as long as wide medially, and $6 \times$ as long as wide apically; sparsely covered with fine punctures, punctation denser in basal portion; with longitudinal carina in basal one-third of rostral length. Rostral pleurostomal sinus deep and membranous. Mandibles externally dentated. Maxillary palpi four-articled. Gular suture single. Compound eyes rather large, subspherical, strongly convex.

Antennae. With 11 antennomeres, not geniculate, with distinct three-antennomered club; moderately long, about $0.7 \times$ as long as rostrum length, reaching anterior onethird of pronotum, inserted in basal one-third of rostral length, sparsely covered with semierect setae; scape cylindrical, $2 \times$ as long as wide, $0.6 \times$ as long as antennomere 2 , antennomeres 2-6 elongate-oval, antennomere 3 about $1.3 \times$ as long as antennomere 2, antennomeres 7-8 short, slightly dilated apically, antennal club about as long as antennomeres 5-6 combined, antennomere 9 as long as wide, dilated apically, wide, about $2 \times$ as wide as antennomere 8; antennomere 10 slightly transverse, dilated apically, wide, antennomere 11 elongate oval with tapered apex; relative length ratios of antennomeres $1-11$ equal to $7: 11: 14: 11: 9: 6: 5: 3: 5: 5: 7$.

Pronotum. Nearly as long as wide, widest medially, narrowed posteriad and anteriad; densely covered with small punctation (punctures distinctly larger than punctures of head), distance between punctures about $0.3-1.1 \times$ diameter of one puncture (punctation on disc sparser); disc evenly convex; lateral margins convex medially and subparallel anteriorly and posteriorly, posterior margin straight, anterior margin convex in dorsal view.

Scutellum. Subpentagonal with widely rounded apex, transverse, about $1.25 \times$ as wide as long, rather large, densely covered with fine punctation.

Elytra. Almost rectangular, elongated, widest behind middle, convex, not ribbed, in anterior one-third slightly impressed medially; elytral base distinctly wider than posterior pronotal margin; humeral callus weak; elytral punctation small and dense, forming regular rows (distinct in basal half), intervals flat; elytral apices rounded together, without large depressed spots and hair stains.

Thorax. Prohypomera with small, dense punctation (as pronotal punctation). Epipleuron narrow. Metaventrite and metepisternum with fine and very dense punctation.

Legs. Long, slender. Femora spindle-shaped, slightly flattened, covered with fine, sparse punctation. Tibiae cylindrical, almost straight, slightly dilated distally, with fringe of dark spinula apically, lacking costate dorsal margin. Tarsi distinctly shorter than tibiae, protarsus about $0.5 \times$ as long 

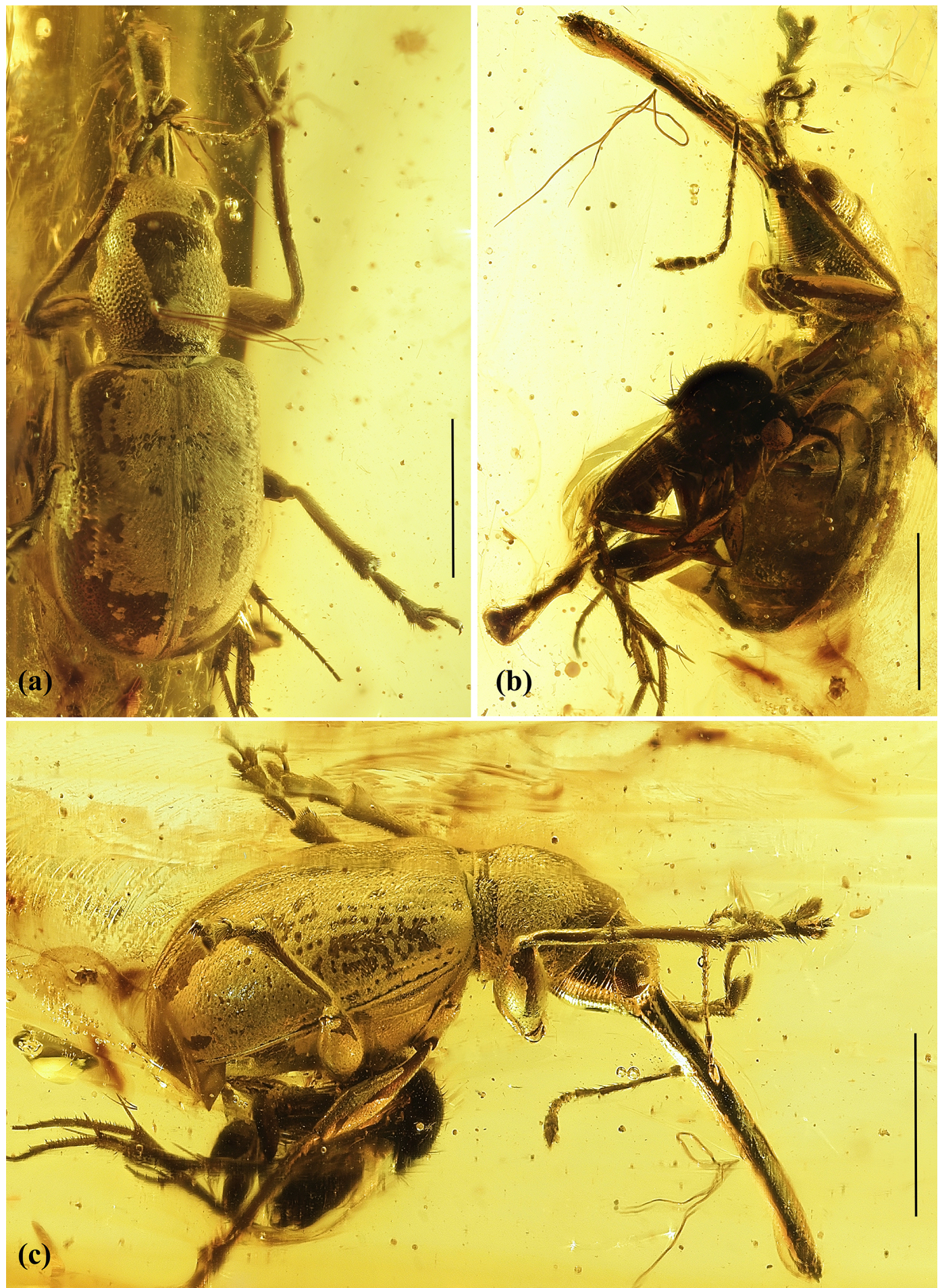

Figure 3. Photomicrographs of Pseudomesauletes lobanovi sp. nov., holotype, 6701 (MAIG), habitus: (a) dorsal view; (b) ventro-lateral view; (c) right lateral view. Scale bars $=1.0 \mathrm{~mm}$. 
as protibial length; tarsomere 1 trapezoidal, elongate, not extended, tarsomere 2 trapezoidal, distinctly dilated apically, tarsomere 3 wide, deeply bilobed, with dense setation ventrally, terminal tarsomere elongated, subcylindrical, slightly curved. Tarsal claws slightly divergent, free, with long spine basally.

Abdomen. Convex, covered with small punctation; ventrites almost homonomous; ventrites 1-3 fused; ventrite 2 $1.4 \times$ as long as ventrite 1 ; ventrite 3 subequal to ventrite 2 and $2.1 \times$ as long as ventrite 4 ; ventrite 4 about $1.7 \times$ as long as ventrite 5 ; ventrite 5 smallest, with rounded apical margin.

\section{Note}

The specimen is a female: elytral apex lacks hair stains, and abdominal ventrites $1-3$ are fussed.

\section{Comparison}

Pseudomesauletes lobanovi sp. nov. is similar to the North American Eocene species $P$. culex (Scudder, 1893) and $P$. ibis (Wickham, 1912), in the long rostrum, almost equal to the length of the elytra. The new species differs from $P$. culex in the large eyes; longer pronotum, $0.44 \times$ shorter than elytra $(0.25 \times$ shorter than elytra in $P$. culex $)$; and slightly smaller body size. It differs from $P$. ibis in the small body size, rostrum shorter than elytra, and weakly convex pronotum. Additionally, the new species differs from P. groehni Bukejs et Legalov, 2019 from Rovno amber in the long rostrum and narrower antennae club.

\section{Key to the Eocene species of the genus Pseudomesauletes}

1. Rostrum 1.4 times as long as elytra. Body large, $7.0 \mathrm{~mm}$. Florissant (ibis (Wickham, 1912)).

- Rostrum shorter than elytra. Body less than $6.1 \mathrm{~mm}$ (p. 2).

2. Rostrum longer, $0.92-0.96 \times$ shorter than elytra (p. 3).

- Rostrum shorter, $0.58-0.85 \times$ shorter than elytra (p. 4).

3. Eyes large. Pronotum $0.44 \times$ as long as elytra. Body length $3.3 \mathrm{~mm}$. Baltic amber (lobanovi sp. nov.).

- Eyes small. Pronotum $0.25 \times$ as long as elytra. Body length $4.2 \mathrm{~mm}$. Florissant (culex (Scudder, 1893)).

4. Rostrum longer, $0.85 \times$ shorter than elytra. Body large (6.1 mm). Florissant (obliquus (Wickham, 1913)).

- Rostrum shorter, $0.57-0.58 \times$ shorter than elytra. Body smaller, 3.2-4.9 mm (p. 5).

5. Body larger, $4.9 \mathrm{~mm}$. Rostrum $4.0 \times$ as long as wide apically. Florissant (striaticeps (Wickham, 1911)).
- Body smaller, $3.2 \mathrm{~mm}$. Rostrum $6.25 \times$ as long as wide apically. Rovno amber (groehni Bukejs et Legalov, 2019).

\section{Remarks}

The studied amber specimen belongs to the family Rhynchitidae based on the not geniculate antennae, single gular suture, narrow epipleuron, four-articled maxillary palpi, ventrites 2 and 3 subequal in length, not extended tarsomere 1, tarsal claws free at base, and deep and membranous rostral pleurostomal sinus. Slightly divergent tarsal claws suggest its placement in the subfamily Rhynchitinae and externally dentated mandibles - in the supertribe Rhynchititae. Rounded apex of the elytra when both together confirm the assignment of the species to the tribe Auletini. The new species belongs to the subtribe Pseudomesauletina based on the tarsal claws with a spine, tibia lacking costate dorsal margin and antennae being inserted before middle of the rostrum. The body is covered with short sparse recumbent setae, elytra are not ribbed, elytral apices are without large depressed spots, antennomere 3 is longer than antennomere 2, antennae are inserted before the middle of the rostrum, and eyes are strongly convex, which suggest placement in the genus Pseudomesauletes. The specimen was assigned to the subgenus Pseudomesauletes $s$. str. on the basis of the almost rectangular elytra and the brown body colouration.

\section{Discussion}

The fauna of the Eocene Rhynchitidae is rather diverse and tribes Sayrevilleini, Auletini, Rhynchitini, and Eugnamptini are found in its deposits (Legalov, 2020b). The subfamily Sayrevilleinae is represented by three tribes (Legalov, 2015a, 2018). Recent Minurini Legalov, 2003 and Vossicartini Legalov, 2003 are distributed in Chile, Argentina, and Africa (Legalov, 2007, 2018). The Sayrevilleini is an extinct tribe and known from fossils only (Fig. 4). The genus Baltocar is found in Eocene Baltic amber but not found in other Paleogene deposits (Legalov, 2020b). The closely related genus Sayrevilleus Gratshev et Zherikhin, 2000, which is very close to it, was described from the Late Cretaceous amber of New Jersey. The genus Orapauletes Legalov, 2009 was described from the Turonian lacustrine, Orapa, Cretaceous of Botswana. Due to the absence of the recent representatives of the tribe Sayrevilleini, the trophic links of its representatives are difficult to determine. It is habitually similar to the recent genera of the subtribe Auletina, which develops on Juniperus and Cupressus (Legalov, 2002). Juniperus are recorded in New Jersey and Baltic amber (Czeczott, 1961; Grimaldi and Nascimbene, 2010). Cupressus is found in Baltic amber (Czeczott, 1961; Alekseev, 2018). Six rather similar species of Baltocar inhabiting the same area were probably associated with different plants. Fourteen species of Cupressaceae are known from Baltic amber (Sadowski et al., 


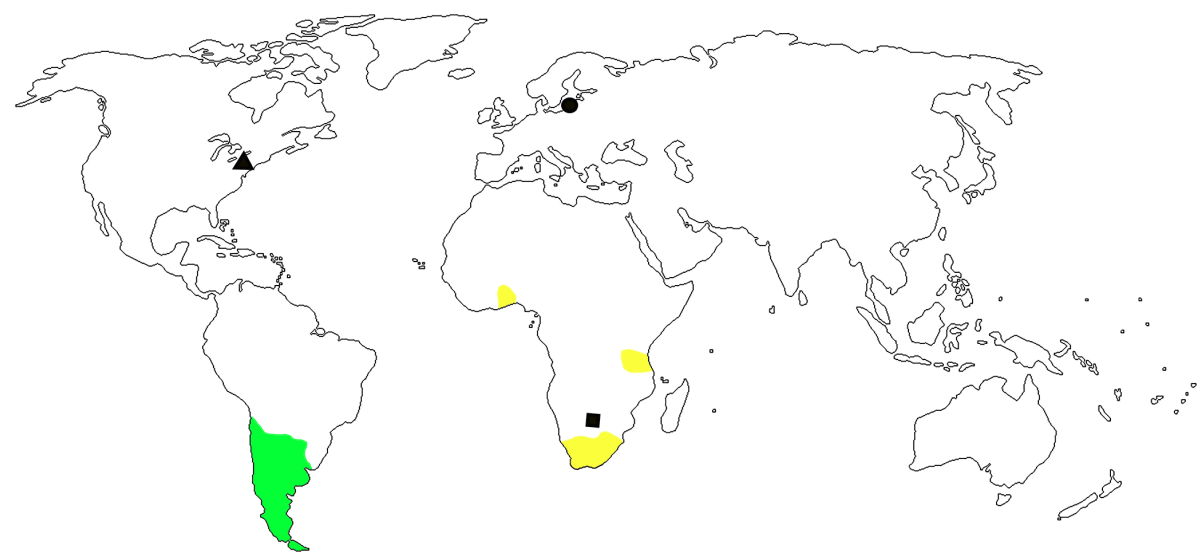

Figure 4. Distribution of Sayrevilleinae: Minurini (green shaded area), Vossicartini (yellow shaded area), and Sayrevilleini: six species of Baltocar from Eocene Baltic amber (black dot), Sayrevilleus grimaldii Gratshev et Zherikhin, 2000 from Late Cretaceous amber of New Jersey (black triangle), and Orapauletes cretaceus Legalov, 2009 from Late Cretaceous formation of Botswana (black square).

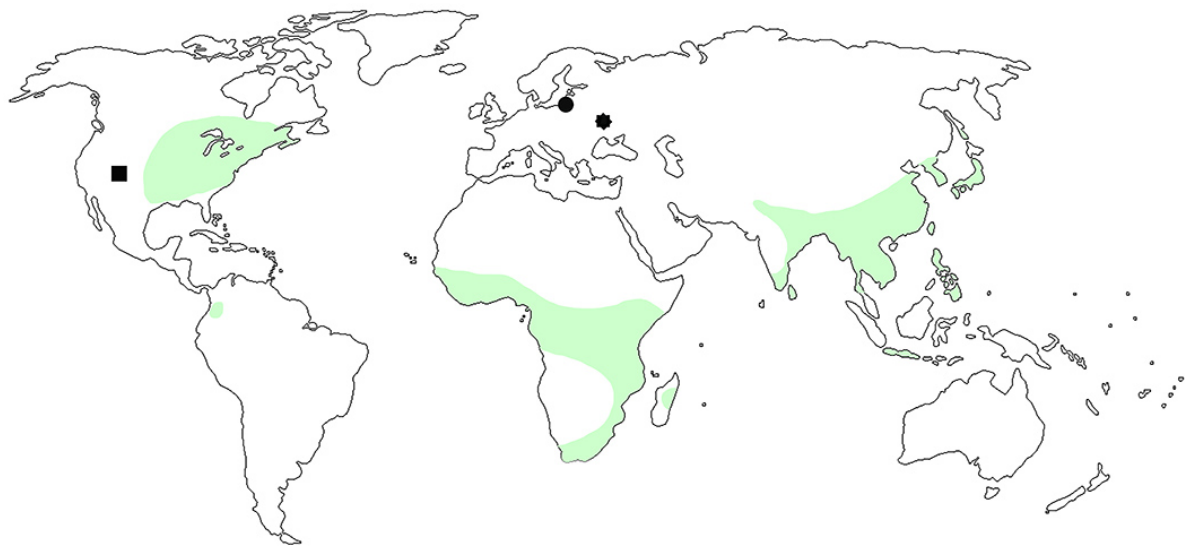

Figure 5. Distribution of the genus Pseudomesauletes with extant (green area) and fossil records: records from Florissant formation, Colorado, USA (black square); record from Rovno amber (black octagon); and P. lobanovi sp. nov. from Baltic amber (black dot).

2017; Alekseev, 2018). It can be assumed that extinct representatives of the genus Baltocar were associated with them.

The genus Pseudomesauletes (Rhynchitinae, Auletini) is distributed in East and South Asia, the Zonda Islands, Africa, Madagascar, North America, and Colombia (Legalov, 2007, 2018), but it is absent in Western Palearctic (Fig. 5). Fossil records are known from the Florissant Formation, Colorado, USA (Scudder, 1893; Wickham, 1912), and Rovno amber (Bukejs and Legalov, 2019). The newly described extinct species from Eocene Baltic amber, P. lobanovi sp. nov., belongs to the species group with the long rostrum almost equal to or longer than the elytra. In the Holocene fauna, such species are absent but are recorded in the Eocene deposit of North America (Legalov, 2015b, 2020b). The trophic relationships of most recent Pseudomesauletes species are unknown (Legalov, 2003). Pseudomesauletes uniformis (Roelofs, 1874) develops in flower buds of Rosa (Lee and Morimoto, 1988), and P. formosanus (Voss, 1921) was recorded on Rubus and Rosaceae (Voss, 1934). Fossil species of Pseudomesauletes were probably related to the family Rosaceae as well, as they quickly differentiated in the Eocene (DeVore and Pigg, 2007) and are found in Baltic (Czeczott, 1961; Weitschat and Wichard, 2002) and Rovno amber (Sokoloff et al., 2018) and in the deposits of Florissant (Manchester, 2001).

Data availability. All material included in this paper is deposited in the Museum of Amber Inclusions, University of Gdańsk, Poland, and all data are included in the description. X-ray microtomography volume renderings of the habitus, habitus of Baltocar sontagae $\mathrm{sp}$ nov., holotype, 6703 (MAIG) an available as a Video Supplement.

Video supplement. Volume renderings of X-ray microtomography of the habitus of Baltocar sontagae, holotype, 6703 (MAIG). The video is available at https://doi.org/10.5446/51994 (Bukejs and Legalov, 2021). 
Author contributions. AB and AAL designed the study, drafted the manuscript, and contributed to the writing and discussion. AB prepared new species descriptions and plates. AAL corrected new species descriptions and performed new systematic taxa placement.

Competing interests. The authors declare that they have no conflict of interest.

Acknowledgements. The authors are sincerely grateful to Elżbieta Sontag (Museum of Amber Inclusions, University of Gdańsk, Poland) for the loan of interesting fossil specimens, to Kristaps Kairišs (Daugavpils University, Daugavpils, Latvia) for assistance in X-ray micro-computed tomography, and to Jonas Damzen (Vilnius, Lithuania) for assistance during our amber research and permission to use photographs of studied specimens. We thank Leonid A. Friedman (Tel Aviv University, Israel) and Vitalii I. Alekseev (Kaliningrad Regional Amber Museum, Russia) for their helpful comments and corrections to an earlier version of this paper.

Review statement. This paper was edited by Carolin Haug and reviewed by Leonid Friedman and Vitalii Alekseev.

\section{References}

Alekseev, P. I.: The revision of gymnosperm species from Eocene Baltic amber, Botanicheskii Zhurnal, 103, 229-245, 2018.

Bukejs, A. and Legalov, A. A.: The first record of Rhynchitidae (Coleoptera) from Rovno amber, Entomol. Fennica, 30, 168172, https://doi.org/10.33338/ef.87173, 2019.

Bukejs, A. and Legalov, A. A.: Baltocar sontagae, holotype, 6703 [MAIG], X-ray micro-CT volume rendering of the habitus, TIB, https://doi.org/10.5446/51994, 2021.

Bukejs, A., Alekseev, V. I., and Pollock, D. A.: Waidelotinae, a new subfamily of Pyrochroidae (Coleoptera: Tenebrionoidea) from Baltic amber of the Sambian peninsula and the interpretation of Sambian amber stratigraphy, age and location, Zootaxa, 4664, 261-273, https://doi.org/10.11646/zootaxa.4664.2.8, 2019.

Czeczott, H.: The flora of the Baltic amber and its age, Prace Muz. Ziemi, 4, 119-145, 1961.

Desbrochers des Loges, J.: Faunule des Coléoptères de la France at de la Corse. Curculionides de la tribu des Attélabides et Rhinomacérides, Le Frelon, 16, 1-80, 1908.

DeVore, M. L. and Pigg, K. B.: A brief review of the fossil history of the family Rosaceae with a focus on the Eocene Okanogan Highlands of eastern Washington State, USA, and British Columbia, Canada, Pl. Syst. Evol., 266, 45-57, 2007.

Emery, C.: Über Phylogenie und Systematik der Insekten, Biol. Centralblatt, 5, 648-656, 1886.

Gistel, J.: Faunula monacensis cantharologica. (Fortsetzung), Isis, 7,2 nd to 4 th unnumbered pages in the Section Umschlag (front covers), 1848.

Gratshev, V. G. and Zherikhin, V. V.: The weevils from the Late Cretaceous New Jersey amber (Coleoptera, Curculionoidea), in:
Studies on fossils in amber, with particular reference to the Cretaceous of New Jersey, edited by: Grimaldi, D. A., Backhuys Publishers Leiden, Leiden, the Netherlands, 241-254, 2000.

Grimaldi, D. A. and Nascimbene, P. C.: Chapter 10: Raritan (New Jersey) amber, in: Biodiversity of fossils in amber from the major world deposits, edited by: Penney, D., Siri Scientific Press, Manchester, 167-191, 2010.

Heer, O.: Die Insektenfauna der Tertiargebilde von Oeningen und von Radoboj in Croatien. Erste Theil. Käfer, Neue Denksch. Allgem. Schweizer. Gesellsch. Gesam. Naturwiss. (Leipzig), 8, 1230, 1847.

Kania, J. and Legalov, A. A.: A new genus of tooth-nosed snout weevils (Coleoptera: Rhynchitidae) in Baltic amber, Paleontol. J., 53, 58-62, https://doi.org/10.1134/S0031030119100083, 2019.

Kuschel, G.: Reappraisal of the Baltic amber Curculionoidea described by E. Voss, Mitt. Geol. Paläontol. Inst. Hambg., 73, 191215, 1992.

Latreille, P. A.: Histoire Naturelle, Générale et Particulière, des Crustacés et des Insectes. Ouvrage faisant suite aux Oeuvres de Leclercq de Buffon, et partie du Cours complet d'Histoire naturelle rédigé par C. S. Sonnini, membre de plusieurs Sociétés Savantes. 3, 440 Dufart, Paris, xii + 467 pp., 1802.

Lawrence, J. F., Beutel, R. G., Leschen, R. A. B., and Ślipiński, S. A.: Chapter 2. Glossary of Morphological Terms, in: Handbook of Zoology. Arthropoda: Insecta. Tb. 40: Coleoptera (Beetles), Vol. 2: Morphology and Systematics (Elateroidea, Bostrichformia, Cucujiformia partim), edited by: Kristensen, N. P. and Beutel, R. G., Walter de Gruyter, Berlin/New York, 9-20, 2010.

Lee, C.-Y. and Morimoto, K.: Larvae of the weevil family Attelabidae of Japan. Part 2. Subfamily Rhynchitinae (Insecta; Coleoptera), J. Fac. Agr., Kyushu Univ., 32, 239-254, 1988.

Legalov, A. A.: Revision der holarktischen Auletini (Coleoptera, Attelabidae), Rus. Entomol. J., 10, 33-66, 2001.

Legalov, A. A.: Revision der Gattung Auletes Schoenherr (Coleoptera, Rhynchitidae, Auletini), Bull. Inst. Roy. Sci. Nat. Belg. Entomol., 72, 175-180, 2002.

Legalov, A. A.: Taxonomy, classification and phylogeny of the leafrolling weevils (Coleoptera: Rhynchitidae, Attelabidae) of the world fauna, Novosibirsk, CD-R. No. 0320301200, 733+350 pp., $641 \mathrm{Mb}, 2003$.

Legalov, A. A.: A new classification of ecological groups of the leaf-rolling weevils (Coleoptera: Rhynchitidae, Attelabidae), Evraziatskii Entomologicheskii Zhurnal, 3, 43-45, 2004.

Legalov, A. A.: Leaf-rolling weevils (Coleoptera: Rhynchitidae, Attelabidae) of the world fauna, Agro-Siberia, Novosibirsk, 523 pp., 2007.

Legalov, A. A.: Contribution to the knowledge of the Mesozoic Curculionoidea (Coleoptera), Amurian Zoological Journal, 1, 283295, 2009.

Legalov, A. A.: New curculionoid beetles (Coleoptera: Curculionoidea) from the Baltic amber, Paleontol. J., 46, 262-272, https://doi.org/10.1134/S0031030112030094, 2012.

Legalov, A. A.: New and little known weevils (Coleoptera: Curculionoidea) from the Paleogene and Neogene, Hist. Biol., 25, 59-80, https://doi.org/10.1080/08912963.2012.692681, 2013.

Legalov, A. A.: The family Rhynchitidae (Insecta: Coleoptera) in the Himalayas, Biodiversität und Naturausstattung im Himalaya, 5, 479-486, 2015a. 
Legalov, A. A.: Fossil Mesozoic and Cenozoic weevils (Coleoptera, Obrienioidea, Curculionoidea), Paleontol. J., 49, 1442-1513, https://doi.org/10.1134/S0031030115130067, 2015b.

Legalov, A. A.: Annotated key to weevils of the world. Part 1. Families Nemonychidae, Anthribidae, Belidae, Ithyceridae, Rhynchitidae, Brachyceridae and Brentidae, Ukr. J. Ecol., 8, 780-831, https://doi.org/10.15421/2018_280, 2018.

Legalov, A. A.: A review of the Curculionoidea (Coleoptera) from European Eocene ambers, Geosciences, 10, 1-74, https://doi.org/10.3390/geosciences10010016, 2020a.

Legalov, A. A.: Fossil history of Curculionoidea (Coleoptera) from the Paleogene, Geosciences, 10, 1-50, https://doi.org/10.3390/geosciences10090358, 2020 b.

Linnaeus, C.: Systema Naturae per regna tria naturae, secundum classes, ordines, genera, species, cum caracteribus, differentiis, synonymis, 10, L. Salvii, Holmiae, 824 pp. 1758.

Manchester, S. R.: Update on the megafossil flora of Florissant, Colorado, Denver Mus. Nat. Sci., Ser. 4, 137-161, 2001.

Poinar, G. O. and Brown, A. E.: Eugnamptus proterus sp. n. (Coleoptera: Curculionoidea: Rhynchitidae), a tooth-nosed snout beetle in Mexican amber, Proc. Entomol. Soc. Washington, 109, 880-885, 2007.

Poinar, G. and Legalov, A. A.: Two new species of the genus Rhynchitobius Sharp, 1889 (Coleoptera: Rhynchitidae) in Dominican amber, Ann. Soc. Entomol. France (N.S.), 51, 70-77, https://doi.org/10.1080/00379271.2015.1059996, 2015.

Riedel, A.: Species descriptions, in: Riedel, A., dos Santos Rolo, T., Cecilia, A. and van de Kamp, Th.: Sayrevilleinae Legalov, a newly recognised subfamily of fossil weevils (Coleoptera, Curculionoidea, Attelabidae) and the use of synchrotron microtomography to examine inclusions in amber, Zool. J. Linn. Soc., 165, 773-794, https://doi.org/10.1111/j.10963642.2012.00825.x, 2012.

Riedel, A., dos Santos Rolo, T., Cecilia, A., and van de Kamp, Th.: Sayrevilleinae Legalov, a newly recognised subfamily of fossil weevils (Coleoptera, Curculionoidea, Attelabidae) and the use of synchrotron microtomography to examine inclusions in amber, Zool. J. Linn. Soc., 165, 773-794, https://doi.org/10.1111/j.1096-3642.2012.00825.x, 2012.

Roelofs, W.: Curculionides recueillis au Japon par M. G. Lewis, Ann. Soc. Entomol. Belgique, 17, 121-176, 1874.
Sadowski, E.-M., Seyfullah, L. J., Schmidt, A. R., and Kunzmann, L.: Conifers of the 'Baltic amber forest' and their palaeoecological significance, Stapfia, 106, 1-73, 2017.

Sadowski, E.-M., Schmidt, A. R., and Denk, T.: Staminate inflorescences with in situ pollen from Eocene Baltic amber reveal high diversity in Fagaceae (oak family), Willdenowia, 50, 405-517, https://doi.org/10.3372/wi.50.50303, 2020.

Scudder, S. H.: Tertiary rhynchophorus Coleoptera of the United States, Mon. US Geol. Surv., 21, 1-206, https://doi.org/10.3133/m21, 1893.

Sokoloff, D. D., Ignatov, M. S., Remizowa, M. V., Nuraliev, M. S., Blagoderov, V., Garbout, A., and Perkovsky, E. E.: Staminate flower of Prunus s. 1. (Rosaceae) from Eocene Rovno amber (Ukraine), J. Plant Res., 131, 925-943, https://doi.org/10.1007/s10265-018-1057-2, 2018.

Voss, E.: H. Sauter's Formosa-Ausbeute. Curculionidae: Rhynchitinae (Col.) (4. Beitrag zur Kenntnis der Curculioniden), Arch. Naturgeschichte, 87, 277-286, 1921.

Voss, E.: Monographie der Rhynchitinen-Tribus Auletini. III Teil der Monographie der Rhynchitinae-Pterocolinae (37. Beitrag zur Kenntnis der Curculioniden), Stett. Entomol. Zeit., 95, 109-135, 330-344, 1934.

Voss, E.: Einige Rhynchophoren der Bernsteinfauna (Col.), Mitt. Geol.-Paläontol. Instit. Univ. Hamburg, 22, 119-140, 1953.

Weitschat, W. and Wichard, W.: Atlas of plants and animals in Baltic amber, Verlag Dr. Friedrich Pfeil, Münich, Germany, 256 pp., 2002.

Wickham, H. F.: Fossil Coleoptera from Florissant, with descriptions of several new species, B. Am. Mus. Nat. Hist., 30, 53-69, 1911.

Wickham, H. F.: A report on some recent of fossil Coleoptera from the Miocene Shales of Florissant, Bull. Lab. Nat. Hist. St. Univ. Iowa, 6, 3-38, I-VIII, 1912.

Wickham, H. F.: Fossil Coleoptera from the Wilson Ranch near Florissant, Colorado, Bull. Lab. Nat. Hist. State. Univ. Iowa, 6, 3-29, I-VII, 1913. 